\title{
Paternalism, Patriarchy and Afrikaans
}

\author{
ROBERT ROSS \\ Rijksuniversiteit, Leiden
}

There have recently been a number of attempts to view the relations between the owners of South Africa's farms and those who worked on their land as in some sense imbued with paternalism or patriarchy. These arguments relate primarily, though not exclusively, to the rural history of the Cape Colony in the eighteenth and nineteenth centuries. Thus Robert Shell sees control over Cape slaves as being legitimated by the ideology of the family, into which slaves were incorporated as 'the most junior members of the patriarchal family'. Although there are significant differences of interpretation between him and Shell, John Mason too sees the 'slaveholding patriarchal household' or familia significantly he has to use the Latin term - as 'the basic social and economic unit of Cape society'. Patriarchal is used to refer to a family structure in which fathers control the lives and labor of family members - wife, children, slaves, and servants' ${ }^{2}$ Clifton Crais takes over much of these arguments, citing Shell approvingly on the slaves' position within patriarchal households. He then extends the argument away from the slave-worked sector of the Cape economy - crudely put, Cape Town and wine and wheat farms of the Boland and Swartland - to include the relations between interior trekboers and their Khoisan labourers. ${ }^{3}$

In this article it is argued that these views, which essentially derive from an attempt to import specific aspects of the historiography on slavery in the United States to South Africa, are mistaken. The basic reason for the error is linguistic. Etymologically, both 'paternalism' and 'patriarchy' derive from the

1. R. Shell, The Family and Slavery at the Cape, 1680-1808, in W.G. James and M. Simons, eds, The Angry Divide: Social and Economic History of the Western Cape (Cape Town, 1989), citation on p. 29. Shell's thesis, Slavery at the Cape of Good Hope, 1680-1731' (PhD thesis, Yale University, 1986), and no doubt his forthcoming book, Children of Bondage: 1 Social History of the Slave Society at the Cape of Good Hope, 1652-1838, elaborate the matter.

2. J.E. Mason, "Fit for Freedom": The Slaves, Slavery and Emancipation in the Cape Colony, South Africa, 1806 to 1842 ' (PhD thesis, Yale University, 1992), 150. See also his articles cited below in note 10 .

3. C.C. Crais, White Supremacy and Black Resistance in Pre-Industrial South Africa: The Making of the Colonial Order in the Eastern Cape, 1770-1865 (Cambridge, 1992), 33-5, 40-7, 55-63. 
Greek and Latin words for 'father', and moreover are recognised as doing so. (There are plenty of concepts whose etymology is no longer evident, and therefore no block to understanding.) As George Fredrickson has written: 'Paternalism can be defined in various ways, but presumably it must involve some sense of quasi-kinship transcending barriers of caste or race, ${ }^{, 4}$ It is this idea 'quasi-kinship', of 'fatherhood', in a metaphorical sense, which is absent from the South African past, at least of that of the Cape Colony in the eighteenth and nineteenth centuries with which this article will be primarily concerned.

The arguments which make use of the concepts of paternalism and patriarchy can be reduced to four propositions. These are:

I. That the dominant individuals on South Africa's farms, and everywhere else in the country for that matter, were and still are almost always adult males.

This is clearly true and important insights have followed from recognition of its truth. The addition of gender to make a trinity with 'race' and 'class' has greatly enriched our understanding of the structures of domination in South Africa, past, present and future. However, there is no reason why males should be fathers, or should behave as such - however fathers may behave - towards those who are not both their biological and their social children.

II. That those dominant individuals recognised that their dominance entailed duties as well as rights.

This, what I may call a weak' paternalism, is certainly an arguable position for many times and places in the past of the South African countryside. As such it allows the setting of questions which were precluded by arguments such as those of Robert Ross and Nigel Worden, which stressed the violence inherent in the maintenance of control on at least the slave-worked farms of the Cape Colony. ${ }^{5}$ Certainly, it should be recognised that there was no such simple entity as Cape slavery and that the forms of control on each farm might be specific to that single farm. Just as one case is known where the slaves are said to have

4. G.M. Fredrickson, 'Masters and Mudsills: The Role of Race in the Planter Ideology of South Carolina' in The Arrogance of Race: Historical Perspectives on Slavery, Racism, and Social Inequality (Middletown, Connecticut, 1988), 19.

5. R. Ross, Cape of Tomnents: Slaveny and Resistance in South Africa (London, 1982); N. Worden, Slavery in Dutch South Africa (Cambridge, 1985). 
reduced the owner to a cipher and taken over the the running of the farm, ${ }^{6}$ so undoubtedly there were - many more - occasions of farms run along the lines of 'weak' paternalism. In general, however, it has proved difficult to provide clear cases of paternalistic behaviour and attitudes on the part of Cape slave owners. Perhaps it is in the nature of the phenomenon and of the specific nature of the Cape's historical records that it should leave little trace. The mass of our information on specific events on the Cape's farms before the last decade of slavery derives from the Cape's voluminous crime records. These, almost by definition, deal with occasions when something has gone wrong. A slave regime run on paternalistic principles and succeeding in its aims, if such ever existed, would be precluded, by its very success, from appearing in the crime records, and thus in historians' fields of vision. Rather it would have to sought in the diaries of the slave-owning class, in ex-slave autobiographies and in oral histories, recorded from them. These classes of material are abundant for the United States and are virtually absent for the Cape Colony. However, it would be a flawed methodology which would argue that a phenomenon can be assumed to have existed if two conditions are satisfied: first, that it demonstrably existed in some other, reasonably analogous, context; and, secondly, that the evidence that it existed is for very good reasons not going to be found. At the very least, some form of corroboration from other indirect sources would be needed. What I would suggest is that the possible corroborative tests all indicate that the analogy with the United States is unfounded, even if the American arguments are as solid and as unchallenged as has been assumed by their South African exponents. 7

Matters are somewhat different for the last decades of slavery, both in terms of the evidence and, perhaps, in terms of the reality on the ground. From around 1815 on, the British government was propagating a weak version of paternaism, and trying to persuade the slave-owners that it was in their interest to behave nicely towards their slaves. ${ }^{8}$ This was part of the campaign which had led to the establishment of the circuit court and the prosecution, albeit generally unsuccessful, of various farmers for having maltreated, or indeed murdered, their Khoisan servants. Obviously, it was thought necessary to temper the attack on brutal masters with some exhortation to others to behave in an acceptable fashion towards their underlings, whether slave or Khoisan.

6. H.CV Leibbrand, Precis of the Archives of the Cape of Good Hope: Requesten (Memorials), 2 vols (Cape Town, 1905), 11, 771.

7. For arguments that paternalism was at best a minority tradition among American slaveholders, see, for example, Fredrickson, 'Masters and Mudsills'; J. Oakes, The Ruling Race: A History of American Slaveholders (New York, 1982), esp. 192-224.

8. S. Trapido, 'From Paternalism to Liberalism: The Cape Colony 1820-1834', International History Review, 12, 1 (1990), 76-104. 
In general, the accusations which the early circuit courts had to deal with had been brought before them by missionaries on behalf of the aggrieved Khoisan. At that time, slaves had no suitable intermediaries, apart from the neighbours of their masters perhaps, with which to lodge their complaints. The missionaries working among the slaves did not consider this form of social advocacy to be part of their task. ${ }^{9}$ The appointment of the protectors of slaves in 1826 introduced an arena in which slaves could call their masters to account for matters which, though serious enough, were less than the murder or maiming which had previously been the only acceptable grounds. The protectors, however, had their own criteria. It soon became clear that slaves able to present an image of themselves as suitably subservient individuals were much more likely to receive satisfaction at the hands of the protectors than those whose behaviour was not thought appropriate. Conversely, the threat of action by the protectors could induce slave-owners to ameliorate their behaviour towards their slaves and to cast their arguments in terms which would appeal to the instincts of the British army officers who had been appointed as protectors. It cannot be chance that the clearest expressions of a paternalist ethos on the part of Cape slave-holders with regard to their slaves can be found in submissions to the protectors of slaves. Both slave-owners and slaves had discovered the instrumental value of a particular framework of discourse. ${ }^{10}$

This sort of material can only be found for a short period of the Cape's history, in a very specific context. Since this is the case, those who would use this material have to make a judgement on the issue of the representativeness of the ideas which are expressed in these statements, and to some extent of the sincerity of those who made them. There seem to be two possible explanations for the limited temporal occurrence of these statements, and the fact that they only appear in a particular context, namely that involving the triangular relationship of slave, slave-owner and protector. On the one hand, the presence of the protectors merely gave both the slave-owners and the slaves the opportunity to articulate for their contemporaries, and incidentally for posterity, a set of attitudes which had long been latently present. In other words, the phenomenon in question may be merely an artifact of the available evidence. Alternatively, these types of statements may have been merely a rhetorical devices adopted to achieve success in a new-fangled arena, and rejected when

9. R. Ross, "The Social and Political Theology of Western Cape Missions in the Early Nineteenth Century', in H.C. Bredekamp and R. Ross, eds, Missions and Christianity in South African History (Johannesburg, forthcoming).

10. The main discussions of these materials are in two articles by J.E. Mason, Hendrik Albertus and his Fx-Slave Mey: A Drama in Three Acts', Joumal of African History, 31,3 (1990), 423 445 and 'The Slaves and their Protectors: Reforming Resistance in a Slave Society, the Cape Colony, 1826-1834', Joumal of Southem African Studies, 19, 1 (195:), 104-128. 
that arena disappeared. If so, it was on occasion successful advocacy and, as is well known, all propaganda must have a kernel of truth for it to have any success. However, in default of other evidence, it seems more probable that the ideas expressed to the protectors were at best a minor strain of both slaveowner and slave thought, brought into temporary prominence because it was effective in a single, specific and short-lived context.

A further location of 'weak paternalism' can be found in the writings of Charles van Onselen on the south-western Transvaal in the first half of the twentieth century, which are themselves based on the reminiscences of old men and women recorded in the major oral history project of the University of the Witwatersrand, a source naturally not available to students of Cape slavery. ${ }^{11}$ Van Onselen describes the close relationships which were built up between share-croppers and Afrikaner landowners in the districts of Bloemhof, Schweizer-Reineke and Wolmaransstad. These clearly reveal the affection and structured interdependence which came into existence, particularly in the fields of leisure activities and religion, in the area. No doubt, the south-western Transvaal was not unique in this, although the long survival of share-cropping relationships in this particular area make it unusual. It would be a mistake, however, to read Van Onselen's results back into any previous period of South African history, and especially not to the Cape. The relations of production between landowners and the rich sharecroppers of the south-western Transvaal were very different from those between slave-owners and their economically much more powerless slaves of the South-Western Cape. ${ }^{12}$

The question is why such cases should be called 'paternalism'. In general, of course, there is a lot to be said for the extreme nominalism of Humpty Dumpty's position on terminology ${ }^{13}$ - if not for his position on the wall, or fence - especially as South African historiography, particularly but by no means exclusively of the Marxist tendency, has been excessively idealist. A definition of paternalism which does not include some form of quasi-kinship is quite feasible. It is quite usual to describe as paternalistic those employers who have come to realise that the optimalisation of profits is best served, not by the

11. C. van Onselen, Race and Class in the South African Countryside. Cultural Osmosis and Social Relations in the Sharecropping Economy of the South-Western Transvaal, 1900-1950; American Historical Review, 95, 1 (1990), 99-123: C. van Onselen, "The Social and Economic Underpinning of Paternalism and Violence on the Maize Farms of the South-Western Transvaal, 1900-1950', Joumal of Historical Sociology, 5, 2 (1992), 127-60.

12. My apologies for the apparently outmoded vocabulary of this sentence.

13. 'When I use a word,' Humpty Dumpty said, in a rather scornful tone, it means just what I choose it to mean - neither more nor less.: L. Caroll, Through the Looking Glass, chapter 6. In M. Gardner, ed, The Armotated Alice (New York, 1960), it occurs on p. 269 in this context, of course, nominalism and idealism refer to positions within late medieval theological debate. 
ruthless exploitation of their labour force, but rather by softer forms of control. ${ }^{14}$ Nevertheless, even such modern employers will often describe their work forces as being one great family. Moreover, there is a very great danger that the use of the term 'paternalism' to describe a situation without some form of kinship ideology will both confuse and entail an unthinking progression to a 'strong paternalism' or patriarchy, as in proposition III.

III. That the dominance of the household or farm head over those who worked on the farm, but who were not his kin, was in some sense an extension of his authority over his wife, children and other members of his kinship group.

There are two arguments involved in this. The more evident is the ideological justification for control over slaves, Khoisan labourers, and later 'coloureds' and Africans. By the definitions of a racist society, these could not be the social children of a farm-owner (though they might of course have been his biological children). The evidence that such non-kin were in some way thought of as junior quasi-kin is meagre in the extreme. Before the advent of the slave protectors, described above, the main evidence for such an argument comes from statements made by lawyers in relation to the punishment of slaves. In one case, the fiscaal explicitly compared the murder of a mistress by a slave to that of a father by a child. The comparison was not made to equate the two acts, however, but to contrast them. A slave murdering his mistress was not committing patricide; he was doing something worse than that, and, at least as 1 read the fiscaal's comments, significantly different. ${ }^{15}$

The second major source, which is regularly cited, is a letter written after the first British conquest of the Cape by the members of the Cape Court of Justice to Major-General Sir James Craig on the measures necessary for the maintenance of good order among the slaves. They wrote

The measures we recommend are the following, viz. that Masters should endeavour to conduct themselves as Fathers rather than as Judges in the Families, and act according to the strictest Rules of Virtue and Humanity, not only in punishing but also in rewarding ... Upon these principles we would flatter ourselves with the hopes that it is not impossible to inspire the Slaves with affection for their Masters, for it is indisputably true that

14. For South African examples, sce P. Harries, Work, Culture, and Identity: Migrant Laborers in Mozambique and South Africa, c. 1860-1910 (Portsmouth, NH, London and Johannesburg, 1994), 71-9, 194 7; W. James, "The Erosion of Paternalism on South African Gold Mines', Industrial Relations Joumal of South Africa, 12 (1992).

15. Cited and discussed in Shell, 'Family and Slavery', 24. 
affection is a reciprocal sentiment, and always increases in proportion to the good actions of him towards whom such Sentiments are exerted. ${ }^{16}$

The problems with using this passage to demonstrate the existence of a paternalist ideology at the Cape are manifold. In the first place, there is the context of this particular piece of argumentation. In this letter, the court was primarily concerned to argue the case for the maintenance of forms of capital punishment in which the victim was tortured to death - not, perhaps, the most paternalist of activities. ${ }^{17}$. These severe measures were necessary not merely because slaves often came from wild and rude Nations, who hardly consider the privation of Life as a punishment, unless accompanied by such cruel circumstances as greatly aggravate their bodily suffering'. In their absence, there would be nothing to deter [the slaves] from revolting against their Masters \& taking advantage of their superior strength'. The paternalist comments later in the letter are clearly a sop to the supposed liberal consciences of the British and, moreover, when read closely, they describe an ideal situation, not one that actually existed.

There is possibly one further way in which the Court's letter could be used to justify a form of paternalism. At a number of moments, they write of a master's 'Family'. In my reading of the text, it is not clear whether by this they refer to a specific kinship group or to the totality of the household over which the 'Master' had authority. The sources of this ambiguity are evident. As lawyers, trained in Roman Law (and some, though not all, of the members of the Court of Justice had such training), they would have been aware of the import of the Latin term familia, which definitely did include slaves, and, in general, all those subject to the authority of the paterfamilias. ${ }^{18}$ As Dutchmen, they would have been accustomed to a much more restricted membership of the familie. In the Netherlands, at least according to the Woordenboek der

16. A du Toit and H. Giliomee, eds, Afrikaner Political Thought: Analysis and Documents: Vol 1 , 17801850 (Berkeley, 1983), 91-3, Mason, 'Hendrik Albertus and his Ex-Slave Mey', 439.

17. Clifton Crais describes the torturing of a victim to death as 'resting precisely on patriarchal power': Crais, White Supremacy and Black Resistance, 229. Whatever feminists might think, the logic behind this statement is strained. It seems to derive from certain claims of Foucault and to be based on two further assumption; first, that Foucault was always right, and, secondly, that his ideas are applicable outside the specific context in which he developed them. Whatever may be thought of the former proposition, the latter is very dubious and has been specifically challenged with regard to Dutch capital punishment by P. Spierenburg, The Spectacle of Suffering. Executions and the Evolution of Repression, from a Pre-Industrial Metropolis to the European Experience (Cambridge, 1984).

18. It is not for nothing that the first modern claims that a patriarchal ideology was important at the Cape is A.M. Hugo, The Cape Vernacular (Cape Town, 1970), the inaugural lecture by a Professor of Classics. On the (non-)applicability of these concepts from Roman law at the Cape, see below. 
Nederlandsche Taal, this term was hardly ever extended beyond the kinship group, ${ }^{19}$ although it does refer to the extended family, and is thus implicitly contrasted with the gezin, or nuclear family.

Of course, the semantic content of the term in the Netherlands may well have been transformed in a colonial setting to something much more closely approximating to Latin usage. However, I do not believe that this happened. Outside the single rather ambiguous text of the Court of Justice, I know of only one occasion when 'family' was used in the more extended sense. The British Governor of the Cape, Earl Macartney, who, significantly, had no children, did refer to his protege John Barrow as a member of his family, but here he was employing the English language, in which the term historically has been far wider than its Dutch cognate. 20 Hinrich Lichtenstein, in contrast, was probably much closer to Dutch usage when he made a clear distinction between the 'Sclaven, Hottentotten, ubriger Dienerschaft' on the one hand and the 'Familie' of the farm owner Jacob Laubscher on the Berg River, on the other. ${ }^{21}$

Significantly, Wayne Dooling's analysis of the way in which the Roman Law was used at the Cape, by far the most subtle to have appeared so far, does not find occasion to refer to the familia as a source of authority. ${ }^{22}$ Rather, Dooling stresses the universalistic qualities of Roman Law and the fact that slaves were most often tried for delicts for which anyone, irrespective of their status, would have been punished if found guilty. It was, of course, true that slave-owners could escape a verdict of guilty far more easily than slaves, often on the basis of their reputation in the community, and, for many but not all offenses, slaves were punished much more severely than free persons. Neither of these qualifications weaken the arguments made here.

19. Woordenboek der Nederlandsche Taal (Leiden, 1864 -), currently 24 volumes, under familie', there is a single sixteenth-century reference to a wider social group, in what is to my mind an ambiguous context.

20. Macartney to Dundas, 10 July 1797 , in G.McC. Theal, ed., Records of the Cape Colony, 36 vols (london, 1895 1906), 11, 113. The Oxford English Dictionary's first two definitions of 'family' are 'servants of a house or establishment' and 'body of persons who live in one house or under one head'; such definitions are totally absent from the Dutch equivalent. See Oxford English Dicitonary, 10 vols (Oxford, 1888-1928).

21. On this point, the English translation by Anne Plumptre, which is reprinted in the Van Riebeeck Society serics, is careless and does not reproduce the distinction Lichtenstein makes. Compare H. Lichtenstein, Reisen in südlichen Afrika in den Jahren 1803, 1804, 1805 und 1806, 2 vols (reprinted Stuttgart, 1967), 1, 77, with H. Lichtenstein, Travels in Southem Africa in the years 1803, 1804, 1805 and 1806, translated by A Plumptre, 2 vols (reprinted Cape Town, 1928-9), I, 57

22. W. Dooling, Law and Community in a slave Society: Stellenbosch District, c. 1760-1820 (Cape Town, Centre for African Studies, Communications no 23, 1992). 
In any event, the lawyers' views, based on Roman law, were not incorporated into everyday language. Certain contrasts between Dutch and Afrikaans make this clear. In Dutch, both now and in the past, what appear to be kinship terms are just that. Oom, tante, zoon, dochter, neef, and (at least when applied to a woman or girl) nicht are rarely if ever used except with reference to people who are in fact the biological uncles, aunts, sons, daughters, cousins/nephews or cousins/nieces of the speaker. ${ }^{23}$ (There is an exception for 'honourary' ooms and tantes, but these are individual, not categorical titles, and also for suikeroom, the Dutch translation of 'sugar-daddy'.) In the South African version of the language, which came to be Afrikaans - at least as spoken by 'whites' - all these terms have a wider reference. Thus all senior white men and women came to be known as oom and tannie, respectively, and reciprocally they would address those who called them thus as neef and niggie. More importantly, all white male children were known as seuns. ${ }^{24}$. The reason for this was presumably to distinguish them from the jongens. In the Netherlands, jongen is a fairly exact translations of the English 'boy'; in South Africa, it was applied to 'coloured' and black underlings of any age. The same distinction, though without the clear kinship connotations, can be found between meisie or meisiekind (a white girl) and meid (a black female servant).

This use of jongen and meid obviously infantilised those of whom they were used. There were other ways in which this was accentuated. John Mason has argued that giving slave women diminutives as names was part of this process, and $\mathrm{I}$ am inclined to agree with him in this, even though no distinction was made between the names, such as Saartje or Styntje, given to slave women at the Cape and to some Dutch women in the Netherlands well into the twentieth century - perhaps this is more a comment on Dutch gender norms. ${ }^{25}$ Certainly the process was accentuated in the twentieth century by the uniform often provided for at least male domestic servants, which was a simplified version of the sailor suit popular for Victorian boys. ${ }^{26}$

All the same, the use of such terminology had a wider importance, though. It clearly placed the jongens outside the putative kinship group which included the seuns. Linguistically, then, the boundaries of the familie were clearly marked. Putatively, it could include any white, but no blacks. The very words they used demonstrate the fallacy of imputing a paternalist or patriarchal ideology, in the

23. Again, this is based on the relevant entries in the Woordenboek der Nederlandsche Taal, which does mention an extension of meaning for oom, but only in a South African context. Other terms, vader, moeder, broeder, zuster, do have a wider extension, but primarily within the context of the Catholic Church and, perhaps derived from this, nursing.

24. See the expression 'ons seuns op die grens'.

25. Mason, 'Fit for Freedom', 186-8.

26. D.H. Strutt, Clothing Fashions in South Africa (Cape Town and Rotterdam, 1975). 
strict sense, towards 'coloured' or black underlings, to those who spoke them. In this respect at least, the language of Afrikaans betrays its origins in the systems of domination of the rural Cape. ${ }^{27}$

The proposition discussed here has a second implication, which can only be noted. It assumes that rural white families were what is known as patriarchal. This, however, should not be taken for granted. It derives from two main sources. The first consists of a few early nineteenth-century descriptions of Boer households as 'patriarchal' by foreign observers, including Lichtenstein and Donald Moodie. These predate by several decades the first English metropolitan usage of the term in its modern, and indeed literal, sense. Until the $1860 \mathrm{~s}$, according to the Oxford English Dictionary, 'patriarchal' meant above all 'like the (biblical) patriarchs' (Abraham and so forth) ${ }^{28}$ and thus, in the modern terminology, almost 'as transhumant pastoralists'. This certainly seems to have been Lichtenstein's meaning when he wrote, of Barend Burgers in the Sneeuwberg, that life on his farm was once again quite to be compared with the patriarchal. 29 Donald Moodie may have been closer to the modern meaning of the word 'patriarchal' when, a propos of the Graaff-Reinet farmers of the late eighteenth century, he wrote:

the patriarchal power on maintaining household discipline which has naturally arisen out of the circumstances in which the remote inhabitants were placed was patiently submitted to by the Hottentot races while ignorant of their legal rights, - and this submission which is in a great degree attributable to the indolent and childishly improvident nature character

27. The origin of a creole language is far too complex to be reduced to a single process, and this comment in no way invalidates those claims that Afrikaans was in the first instance a language of slaves and Khoe. See ${ }_{i}$ for example, A Davids, Words the Slaves Made: A Socio-HistoricalLinguistic Study, South African Joumal of Linguistics, 8, 1 (1990) 1-24; A Davids, The Afrikaans of the Cape Muslims from 1815-1915' (MA thesis, University of Natal, Durban, 1991), H. den Besten, 'From Khoekhoe Foreignertalk via Hottentot Dutch to Afrikaans: The Creation of a Novel Grammar, in M. Pütz and R. Dirven, eds, Wheels within Wheels: Papers of the Duisburg Symposium on Pidgin and Creole Languages (Frankfurt am Main, 1989), 20748.

28. Other uses of the term, for the church fathers - Augustine and so on - or for the leaders of various Christian churches - the patriarch of Constantinople and so forth do not seem important in this discussion.

29. Das Leben dieser Leute war eirmal wieder ganz dem patriarchalischen za vergleichen .., Lichtenstein, Reisen im Südlichen Afrika, II, 30. In neither the German original nor as translated into English did Lichtenstein say that the farmers followed 'the patriarchal mode of life': see Shell, 'Family and Slavery', 24. 
naturally rendered their treatments less severe than it became when the first symptoms of insubordination appeared. ${ }^{30}$

It should however be pointed out that he was not writing of his own observation, nor did he believe that such docility had lasted. Rather, this passage was written in the course of a diatribe against the missionaries and the ideas of 'Hottentot nationalism' which he saw developing. ${ }^{31}$ At the very least, these sorts of comments have to be treated with considerable caution. It is too easily forgotten that words could have had a theological meaning long before they had an anthropological, let alone a feminist, one.

The second source for the image of the white rural household as patriarchal is the work of Afrikaner nationalist sociologists in the mid-twentieth century, above all Geoffrey Cronje. ${ }^{32}$ While Cronje's political utterances have recently regained a certain notoriety, ${ }^{33}$ his sociological work has only recently begun to be placed in its academic, and to a lesser extent its political, context. $^{34}$ Probably against Cronje's intention, his description of the Afrikaner patriarchal family has also been read as suggesting that the institution was an ideological cover for harsh internal exploitation. ${ }^{35}$ However, it does not require much imagination to see his stress on the patriarchal family as an integral part of the project of conservative Afrikaner nationalism, and thus as myth. Now, myths can of course be at least half-truths, and probably need some basis in truth to achieve any acceptance. Cronje, trained as an empirical

30. Cape Archives, VC 888, D. Moodie, The Social Position of the Colored Classes in this Portion of the Colony from the Year 1786, 2. This is a report written shortly after he had been appointed in 1834 to publish the records of the colony. See R. Ross, Donald Moodie and the Origins of South African Historiography', in R. Ross, Beyond the Pale: Essays on the History of Colonial South Africa (Hanover and London, 1993), 192-212.

31. S. Trapido, "The Emergence of Liberalism and the Making of "Hottentot Nationalism", 18151834', in The Societies of Southern Africa in the 19th and 20th Centuries, vol. 17, 34-59.

32. G. Cronje \& J.D. Venter, Die Patriargale Fanilie: 'n Kultuurhistoriese en Kultuursosiologiese Shudie, 2nd rev. ed. (Cape Town and Pretoria, 1973), and the many references cited in this work.

33. J.M. Coetzee, 'The Mind of Apartheid: Geoffrey Cronje (1907 - )', Social Dynamics, 17, 1 (1991) 1-35; S. Dubow, Afrikaner Nationalism, Apartheid and the Conceptualization of "Race", Joumal of African History, 33, 2 (1992), 229.

34. R.B. Miller, 'Science, Sociology and Social Engineering: South Africa in the 1930s' (Paper presented to the Joumal of Southem African Studies Twentieth-Anniversary Conference, York, September 1994), surprisingly, Cronje and the school of thought he represented is not mentioned in E. Brink, Man-Made Women: Gender, Class and the Ideology of the Volksmoeder', in C. Walker, ed., Women and Gender in Southem Africa to 1945 (Cape Town and London, 1990), 273-92.

35. See, for example, 1. Hofmeyr, Building a Nation from Words: Afrikaans Language, Literature and Ethnic Identity, 1902-1924', in S. Marks and S. Trapido, eds, The Politics of Race, Class and Nationalism in Twentieth Century South Africa (London and New York, 1987), 99. 
sociologist in the best Dutch tradition, undoubtedly believed that he was presenting an accurate, unbiased description. All the same, the ideological content of descriptions of Afrikaner households as patriarchal must be recognised, and the description itself approached with considerable caution. Moreover, the explicit comparisons which Cronje makes between the Afrikaner family - in one of which he claims to have been brought up - and that of the Romans and Hebrews can only increase the suspicion that models from ancient history, and perhaps the one of the original uses of the term patriarch, again greatly influenced his descriptions.

If this is the case, then it would also seem valuable to question the assumption that black families at various times and places in South African history were also patriarchal, although it should be stressed that the questioning of an assumption does not necessarily entail its rejection. Obviously, there is a mass of evidence to show that ideologies and practices which can be described as patriarchal on a loose definition of that word were, and are, widely distributed within South Africa ${ }^{36}$ Equally, there is much reason to suppose that those ideologies and practices were changed, and often strengthened, in the circumstances of segregationist and apartheid South Africa during the twentieth century, often as a result of the alliance between senior males and the white-run state. ${ }^{37}$ On the other hand, within the context of this article it is important to note that the establishment of seemingly patriarchal families was often seen by their members, men, women and children, as an act of liberation. This was particularly the case in the aftermath of slavery and the degradation of the Khoisan. The struggle to create domestic groups free of control from the farmers and slave-owners was particularly fierce on the missions of the Cape Colony from 1792 onwards, and in particular after Emancipation in $1838 .^{38}$ The circumstances in which this happened obviously did much to determine the form which these families then took. In general, the benefits to be gained by conformity to the outward norms of respectability as defined by the whites were very great, although there are indications that consensual unions prior to marriage were more common than missionaries and others would have liked, particularly where clerical control was relatively weak. This may have been seen

36. See, for example, C. Walker, 'Women and Gender in Southern Africa to 1945: An Overview', in Walker, Women and Gender in Southem Africa.

37. HJ. Simons, African Women. Their Legal Status in South Africa (London, 1968); see M. Chanock, Law, Custom and Social Order. The Colonial Experience in Malawi and Zambia (Cambridge, 1985).

38. See P.F. Scully, 'Liberating the Family?: Gender, Labor, and Sexuality in the Rural Western Cape, South Africa, 1823-1853' (PhD thesis, University of Michigan, 1993); E. Elboume and R. Ross, "The Missions to the Cape Colony in the First Half of the Nineteenth Century', in R. Elphick, ed., A History of Christianity in South Africa (forthcoming). 
as a price to be paid, but it was a price which very many men and women were prepared to pay, and indeed to struggle for the right to pay.

IV That the self-humbling attitudes required of underlings by a paternalist ideology were indeed internalised, and formed part of the basis for social control.

This proposition has been attacked even by some of those who would adhere to various of the previous theses, notably by Mason, who points out that slave internalisation of the norms of what he sees as patriarchal households was not sufficient to prevent all but a few slaves leaving those very households the moment the had the chance. After Emancipation, very many slaves moved away from the site of their bondage. ${ }^{39}$ All the same, it is not impossible that the experience of slavery and its successor regimes so warped the personalities of a few of their victims that they came to think in such terms. There is even one letter extant written by a slave man to his mistress which voices such sentiments. ${ }^{40}$ However, as the man in question was suffering from leprosy, and thus confined in the institution of Hemel-en-Aarde, and as the letter was dictated to, or indeed perhaps composed by a Moravian missionary, and certainly came into his possession and was printed to show the beneficial effects of the missions, it should not be taken as firm evidence. In general, such arguments are no more than master-class wishful thinking. ${ }^{41}$

In conclusion, paternalism and patriarchy are not, I believe, useful summaries even of South Africa master-class ideologies, let alone are they of any use as explanations of subaltern docility - which never existed anyway. Nevertheless, the work which has attempted to apply these concepts to South Africa has had the great merit of pointing out that control over people can only be achieved if, on occasion, rewards are given as well as punishments doled out. The question is then what terminology should be used to describe such a system. Afrikaans at least provides a wide choice of seeming synonyms. As Charles van Onselen has written,

39. Mason, 'Fit for Freedom', 189 and chapter 8.

40. Manus Kasten, 7 Oct. 1829, Periodical Accounts relating to the Missions of the Church of the United Brethren, Established among the Heathen, XI, 429.

41. See J. Cock, Maids and Madams: A Study in the Politics of Exploitation (Johannesburg, 1980), 87,132 , in which it is commented that $30 \%$ of employers of domestic servants in and around Grahamstown in the 1970 s saw their employees as members of the family, while not a single employee saw herself as such. 
Only urbanized English-speakers could gloss over the real distinctions that separate plaas kaffers (farm niggers) from volk (folk), mense (farm people) from diensbodes (servants), basters (bastards) from oorlams (the capable ones), or a kneg (serf or bondsman) from a voorman (foreman). ${ }^{42}$

Clearly the linguistic elaboration around the domination of black men and women has provided white Afrikaners with a richness of vocabulary in this field to approach that of the Zulu on cattle or the Inuit on snow. Moreover, these ideas are old. In the early eighteenth century, Adam Tas was already referring to his labourers as 'het volk'. ${ }^{43}$ The words used are clearly a somewhat distorted reflection of ideologies. They can provide an entry into those ideologies in ways which are hidden by the importation of American ways of looking at things into South Africa. Moreover, they allow us to transcend the limitations on our thought provided by juridical status (between slave and free Khoisan, for instance) and later by ascribed racial identity.

This article has been written out of a feeling of unease with current forms of terminology. As yet, I cannot provide concrete examples of how the study of domination and resistance on South African farms will develop when the real insights provided by the 'paternalists' have been incorporated, without the confusing baggage which ideas of paternalism provide. Even Van Onselen has not yet provided 'urbanised English-speakers', who unfortunately will long be the mass of our audience, with a discussion of what the various distinctions in the vocabulary of the south-western Transvaal actually amount to. For the time being, then, I will have to be content with setting some of the questions, not with providing the answers.

42. Van Onselen, 'Race and Class in the South African Countryside, 101-2.

43. L. Fouche, ed., The Diary of Adam Tas, 1705-1706, 2nd rev. ed. (Cape Town, 1970), 63, 65. 